\title{
Impact of nitrogen fertilizers on protein and amylose content in grain of rice varieties grown in different agrolandscapes of Krasnodar region
}

\author{
Natalia Tumanian ${ }^{1, *}$, Tatyana Kumejko ${ }^{1}$, Svetlana Chizhikova ${ }^{1}$, Elina Papulova $^{1}$ and \\ Sergey Garkusha ${ }^{1}$ \\ ${ }^{1}$ Federal State Budgetary Scientific Institution «Federal Scientific Rice Centre», 3, Belozerny, \\ 350921, Krasnodar, Russia
}

\begin{abstract}
The article presents the results of evaluation of rice varieties Flagman, Novator, Favorit, Olimp, Yubileyniy 85, Atlant, Kurazh, Rapan 2, Patriot, Azovsky, Polevik, Kazachok 4, Nautilus, Yakhont, bred in 1996-2019 by Russian breeders and grown in the Abinsky district, Krasnodar region by protein and amylose content in the grain due to the level of nitrogen nutrition during the growing season. The protein content in grain in all varieties with an increase in the applied nitrogen fertilizers from $\mathrm{N}_{90}$ to $\mathrm{N}_{120}$ increased by $0.03-0.56 \%$. In 2016, the varieties Novator, Flagman, Olimp, Atlant, Kurazh, Kazachok 4 were $0.40 \%$ and higher; in the varieties Favorit, Polevik, Yubileiny 85, Patriot, Nautilus and Yakhont by $0.03-0.39 \%$. The variety Patriot showed a slight growth trend in PC. In polished rice, PC decreased in two variants of the experiment to 78.9$91.9 \%$ PC, and the indicator was not dependent on the variant. Under the conditions of rice cultivation at $\mathrm{N}_{120}$, a decrease in the amylose content in grain in varieties by $0.2-0.7 \%$ was observed. There was a general trend of a more significant decrease in AC in varieties in 2018. All varieties were assigned to the group of low amylose varieties with AC from 15.1 to $19.0 \%$.
\end{abstract}

\section{Introduction}

Rice is a crop demanding mineral nutrition. Nitrogen fertilizers play a leading role in increasing rice yields and provide up to $80 \%$ of the yield increase obtained from the use of mineral fertilizers. The results of previous studies indicate the ambiguous effect of the level of mineral nutrition on rice quality. Chinese scientists noted that the effect of the use of nitrogen fertilizers on the culinary and nutritional qualities was very complex (not intended) $[1,2]$. The use of nitrogen $(\mathrm{N})$ and planting density (nutrition area) are two important agronomic factors affecting rice growth, yield and grain quality. Four main aspects of rice grain quality were studied, namely: chopping (brown rice, chopped rice and percentage of heads of rice), appearance (length / width ratio, percentage of chalk kernels and smallness), protein content, nutritional value, culinary advantages (apparent amylose content, gel consistency and bonding viscosity) in rice varieties Shendao 47 and Jingyou 586 at four

* Corresponding author: TNGeraG@yandex.ru 
application rates of $\mathrm{N}$ : 0, 140, 180 and $220 \mathrm{~kg} /$ ha in field trials in 2015, 2016. For all grain quality parameters, no significant interaction was found between the $\mathrm{N}$ absorption intensity and the plant density. A higher absorption rate of $\mathrm{N}$ led to an increase in brown, head rice and chalky kernels, a decrease in the length / width ratio, the apparent content of amylose, the consistency of the gel. These results show that norm $\mathrm{N}$ has a beneficial effect on chopping and nutrition, but a negative effect on the appearance and quality of cooked food. Jingyou 586 and Shendao 47 reacted differently to planting density in terms of grain quality. With an increase in the dose of nitrogen, the mass of 1000 grains and vitreousity increase, the number of fractured, underdeveloped grains and filminess decrease [3].

However, a further increase in the dose leads to the opposite result: vitreousity decreases, the fracturing and the number of underdeveloped grains increase. Foliar application ensures the balance of mineral nutrition in the most important periods of plant growth and development, providing enzyme activity, as a result of which the metabolism in the root system is activated and the intake of nutrients from the soil and their redistribution in plants increase $[4,5,6,7,8]$. In a study conducted by Indian scientists, it was shown that nitrogen fertilizers (urea), in combination with Azolla, significantly increased the yield of varieties, the protein content $(0.1-0.7 \%)$; the use of urea alone reduced amylose content. However, the combined use of azolla and urea reduced the amylose content. The availability of nitrogen from fertilizers affects the growth of rice plants, leaf area, the content of chlorophylls, the absorption of nutrients, significantly increases the yield of rice grain by $18-41 \%$ and the protein content from 0.1 to $0.7 \%$.An experiment was conducted to study the effect of nitrogen fertilizing (the time of applying nitrogen, urea - tillering and the beginning of grain filling) on the development of caryopsis and rice grain quality. Elevated doses of nitrogen during filling can lead to an increase in protein and a decrease in amylose. Amylose content decreased during combined (organic and inorganic nitrogen fertilizers) treatments. The level of nitrogen nutrition affects both the protein content and the amylose content. For all varieties, the protein content (PC) was significantly higher, while the amylose content (AC) was significantly lower at higher doses of nitrogen nutrition. At the same time, lower amylose content when using high doses of nitrogen nutrition leads to an improvement in the culinary and nutritional benefits of milled rice, the opposite effect of a higher protein content was greater than the effect of amylose on grain quality at higher doses of nitrogen nutrition $[3,9]$.

Excessive use of nitrogen fertilizers also contributes to the deterioration of rice culinary advantages. In China, an average of $193 \mathrm{~kg} / \mathrm{ha}$ is used, which is $90 \%$ higher than the average in the world, so in Jiangsu province - an average of more than $300 \mathrm{~kg} / \mathrm{ha}$ [10]. At higher doses of $\mathrm{N}$, the main reason for the deterioration of grain quality is associated with a higher protein content, although a lower amylose content may contribute to improved starch bonding properties. These results indicate that further improvement in grain quality will depend on both the agricultural technology of rice, especially with regard to nitrogen and water management (irrigation regimes and nitrogen fertilizers) [11].

In the Yangtze River Basin, 12 varieties of japonica rice were cultivated, while nitrogen fertilizers were used in three doses: $0 \mathrm{~kg} /$ ha N, $240 \mathrm{~kg} /$ ha N and $360 \mathrm{~kg} / \mathrm{ha} \mathrm{N}$. During the filling phase, the amylose content and gel consistency improved, but the nutritional value of grain decreased due to a decrease in protein content. For all varieties, the protein content was significantly higher, while the amylose content was significantly lower at higher doses of nitrogen nutrition. [12]. In studies conducted in the province of Gilan in Iran in 2008, 2009. under the conditions of 4 options for the applied nitrogen fertilizers: N1, control (without fertilizers N); N2 - $30 \mathrm{~kg} \mathrm{~N} /$ ha; N3 - $60 \mathrm{~kg} \mathrm{~N} / \mathrm{ha} ; \mathrm{N} 4-90 \mathrm{~kg} \mathrm{~N} / \mathrm{ha}$, it is shown that the highest amylose content in the grain was noted in option N1, and with an increase in the dose of nitrogen fertilizers, the amylose content decreased $[13,14]$. 
During grain ripening, nitrogen nutrition also affects starch content and its composition by regulating enzyme activity and gene expression related to starch synthesis. Rice viscosity and taste vary. The results showed that the content of amylopectin in the grain changed depending on the nitrogen supply, during the period of grain filling, nitrogen doses affected the content of starch components in the grain. The quality of cooked rice products with a high amylose content has deteriorated. A decrease in rice protein content could significantly improve the viscosity of rice, and the composition of starch had a great influence on the viscosity properties of rice starch. [14].

Rice grains during filling are most sensitive to the nitrogen state of plants. It is proved that there is an optimal time for applying nitrogen fertilizing, which allows to reduce the number and size of powdery stains in the caryopsis per unit of increase in content [15]. The effect of the applied doses of nitrogen on the accumulation of raw protein and amylose in rice grain on the primary and secondary panicle branches and their taste manifestation was studied. The raw protein content in rice grain on both the primary (PRB) and secondary panicle branches (SRB) increased with an increase in $\mathrm{N}$ supply, indicating a strong negative correlation with palatability. The correlation coefficient between the protein content in the grain by PRB and SRB was -0.92 and -0.98 , respectively. Although the amylose content also decreased with increasing $\mathrm{N}$ supply, the change was not significant for either PRB or SRB. These results show that when breeding for varieties with good taste, plants with a large number of grains on PRB should be selected. By maintaining nitrogen levels in the soil, protein accumulation can be controlled, thereby improving the taste of cooked rice. [16].

Studying the effect of nitrogen fertilizers on the accumulation of reserve protein and the amylose content in grain of Russian rice varieties is relevant in connection with the problem of nutritional value and improving their culinary advantages. The reaction of the new Russian rice genotypes to nitrogen fertilizers due to biochemical traits (the content of amylose and protein in the grain) is not known.

\section{Materials and Methods}

15 rice varieties served as research material: Rapan, Flagman, Novator, Favorit, Olimp, Yubileyny 85, Atlant, Kurazh, Rapan 2, Patriot, Azovsky, Polevik, Kozachok 4, Nautilus, Yakhont bred in the Federal Scientific Rice Centre and grown in 2016-2018 in the Abinsky district, Krasnodar region. The following rice varieties are included in the State Register of Protected Breeding Achievements for the North Caucasus region: Rapan in 1996 (used as a standard), Novator in 2006, Flagman in 2007, Favorit in 2014, Olimp in 2015 Polevik - in 2015, Yubileyny 85 - in 2015, Atlant - in 2016, Kurazh - in 2016, Patriot - in 2017, Kozachok 4 - in 2018, Nautilus - in 2019, Yakhont - in 2019, Azovsky - in 2019, Rapan 2 is currently under state testing. The soil cover is represented by a complex of meadowchernozem medium-thick heavy loamy soils on alluvial clays and heavy loams and meadow medium-thick light-clay soils on alluvial clayed loams (heavy loams). Rice meadow light clay soils are characterized by water-physical properties favorable for rice cultivation. The filtration rate during the irrigation period is $0.002-0.003 \mathrm{~m} /$ day. The groundwater level during the non-growing season is at a depth of $2.0 \mathrm{~m}$ and below. The thickness of the humus horizon is on average $75 \mathrm{~cm}$, the humus content is $5.08 \%$. The reaction of the soil solution in the arable horizon is neutral - $\mathrm{pH}$ 6.8-7.2, gradually increasing to a medium alkaline depth. The amount of absorbed bases reaches $32-42 \mathrm{mEq} / 100 \mathrm{~g}$. The proportion of absorbed calcium is $65-70 \%$, absorbed magnesium - up to $25 \%$. The availability of rice meadow soils with elements of plant mineral nutrition is high. So, the content of gross nitrogen is $0.22-0.26 \%$, total phosphorus is $0.18-0.20 \%$. They are characterized by a high level of effective fertility. The availability of soils with accessible forms of nutrient 
elements for plants is characterized mainly as high. The content of easily hydrolyzable nitrogen compounds is 8.7-10.3 mg / $100 \mathrm{~g}$; mobile forms of phosphorus 9.3-12.2 mg / 100 $\mathrm{g}$; mobile forms of potassium 43.2-45.8 mg / $100 \mathrm{~g}$. Mineral fertilizers were added to top dressing according to the experimental scheme: option $1-\mathrm{N}_{60} \mathrm{P}_{90} \mathrm{~K}_{60}$, option $2-\mathrm{N}_{120} \mathrm{P}_{90} \mathrm{~K}_{60}$. Harvesting was carried out in 2016-2019. from 23.10 to 02.11 .

The determination of amylose was carried out colorimetrically using the Juliano amylose-iodine reaction: grain starch (flour) of rice samples were gelled using a unimolar $\mathrm{NaOH}$ solution, then transferred to an acidic medium; The blue color of the solution after the reaction with iodine was evaluated using a Genesis 8 spectrophotometer at $600 \mathrm{~nm}$. Amylose content was calculated using mixed amylose / amylopectin standards. The determination of protein in husked and polished rice was carried out in accordance with GOST 10846-91 according to Kjeldahl. Protein content was measured using a grain analyzer (KjeltecTM 2300, Foss, Denmark): all the nitrogen of the grain (kernel) is converted to an inorganic form when burned in sulfuric acid, and then its amount is recorded by distillation and titration.

\section{Results and Discussion}

Protein and amylose content in the grain of new rice varieties of Russian breeding was assessed in connection with the nutritional value of rice products and variability of varieties by these traits in the conditions of rice cultivation at various levels of nitrogen nutrition.

Protein is the second largest component in rice grains. Its content in rice grain is small and is in the range (6.6-10.4\%), but in relation to other grain crops, its nutritional value is higher. Rice protein contains all the essential amino acids and is absorbed by the human body by $98 \%$. Rice varieties according to the protein content in grain are divided into groups: with a protein content in milled rice of less than $7.0 \%$, they are classified as low protein, $7.0-8.0 \%$ as medium protein, and more than $8.0 \%$ as high protein. Data on the protein content in husked rice varieties grown with two variants of applied nitrogen fertilizers are presented in Figure 1.

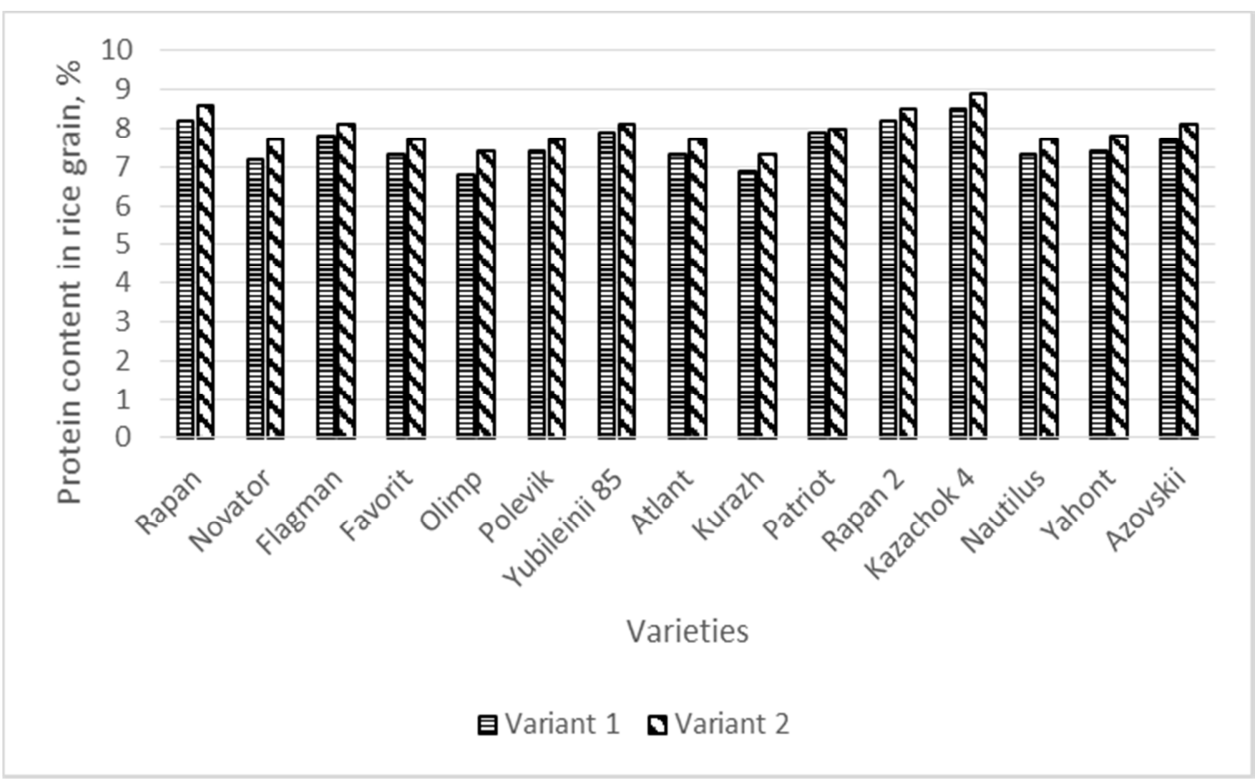

Fig. 1. The protein content in the grain of rice (cargo rice, brown rice) growing conditions at $\mathrm{N}_{90}$ (variant 1) and $\mathrm{N}_{120}$ (variant 2). 
The maximum protein content in rice grain was observed in varieties Rapan, Rapan 2, Kazachok 4 - 7.92-8.92\%, which were classified as high-protein varieties. The lowest protein content - in varieties Olimp, Atlant and Kurazh - 6.54-7.58\%. The protein content in grain in all varieties with an increase in the level of nitrogen nutrition from $\mathrm{N}_{90}$ to $\mathrm{N}_{120}$ increased by $0.03-0.82 \%$. In 2016, in the varieties Novator, Flagman, Olimp, Atlant, Kurazh, Kazachok 4 - by $0.40 \%$ and higher; in the varieties Favorit, Polevik, Yubileiny 85 , Patriot, Nautilus and Yakhont by 0.03-0.39\%. In 2017, for varieties Rapan, Olimp, Rapan 2, Kazachok 4, Nautilus, Atlant, Yakhont, Azovsky - the indicator was higher than $0.40 \%$; for varieties Novator, Flagman, Favorit, Polevik, Yubileiny 85, Kurazh, Patriot - 0.09$0.38 \%$. Within similar limits, an increase in PC occurred under the conditions of variant 2 in the experiment in 2018 and 2019. The variety Olimp showed a maximum increase under conditions of increased nitrogen nutrition of PC in 2017 (by $0.76 \%$ ), in 2018 (by $0.82 \%$ ) and 2019 . (by $0.69 \%$ ). The variety Patriot showed a tendency for a slight increase in PC: in 2016 by $0.03 \%$, in 2017 by $0.09 \%$, in 2018 by $0.19 \%$, in 2019 by $0.10 \%$.

The protein content in polished rice was estimated. The results are presented in Table 1.

Table 1. The protein content in the grain of rice varieties of Russian breeding, grown under various conditions of nitrogen nutrition.

\begin{tabular}{|c|c|c|c|c|c|}
\hline \multirow{2}{*}{ Variety } & \multirow{2}{*}{ Year } & \multicolumn{2}{|c|}{$\begin{array}{l}\text { Protein content in polished } \\
\text { rice. } \%\end{array}$} & \multicolumn{2}{|c|}{$\begin{array}{c}\text { Decrease of protein content } \\
\text { in polished rice. } \%\end{array}$} \\
\hline & & variant 1 & variant 2 & variant 1 & variant 2 \\
\hline \multirow{4}{*}{ Rapan } & 2016 & 7.21 & 7.55 & \multirow{4}{*}{91.0} & \multirow{4}{*}{90.9} \\
\hline & 2017 & 7.38 & 7.74 & & \\
\hline & 2018 & 7.83 & 8.06 & & \\
\hline & 2019 & 7.59 & 7.97 & & \\
\hline \multirow{4}{*}{ Novator } & 2016 & 5.62 & 6.04 & \multirow{4}{*}{78.9} & \multirow{4}{*}{80.0} \\
\hline & 2017 & 5.81 & 6.11 & & \\
\hline & 2018 & 5.61 & 6.32 & & \\
\hline & 2019 & 5.88 & 6.21 & & \\
\hline \multirow{4}{*}{ Flagman } & 2016 & 6.41 & 6.78 & \multirow{4}{*}{83.7} & \multirow{4}{*}{85.2} \\
\hline & 2017 & 6.22 & 6.86 & & \\
\hline & 2018 & 6.81 & 7.10 & & \\
\hline & 2019 & 6.63 & 7.00 & & \\
\hline \multirow{4}{*}{ Favorit } & 2016 & 6.69 & 6.71 & \multirow{4}{*}{91.1} & \multirow{4}{*}{90.5} \\
\hline & 2017 & 6.50 & 6.91 & & \\
\hline & 2018 & 6.81 & 7.22 & & \\
\hline & 2019 & 6.75 & 7.01 & & \\
\hline \multirow{4}{*}{ Olimp } & 2016 & 5.51 & 5.86 & \multirow{4}{*}{84.0} & \multirow{4}{*}{84.1} \\
\hline & 2017 & 5.58 & 6.23 & & \\
\hline & 2018 & 5.92 & 6.61 & & \\
\hline & 2019 & 5.78 & 6.37 & & \\
\hline \multirow{2}{*}{ Polevik } & 2016 & 6.41 & 6.59 & \multirow{2}{*}{86.7} & \multirow{2}{*}{86.0} \\
\hline & 2017 & 6.42 & 6.72 & & \\
\hline \multirow{2}{*}{ Yubileyniy 85} & 2016 & 6.95 & 7.11 & \multirow{2}{*}{90.2} & \multirow{2}{*}{89.8} \\
\hline & 2017 & 7.30 & 7.44 & & \\
\hline \multirow{4}{*}{ Atlant } & 2016 & 5.63 & 6.08 & \multirow{4}{*}{81.0} & \multirow{4}{*}{81.0} \\
\hline & 2017 & 5.81 & 6.21 & & \\
\hline & 2018 & 6.14 & 6.45 & & \\
\hline & 2019 & 5.98 & 6.34 & & \\
\hline \multirow{2}{*}{ Kurazh } & 2016 & 5.76 & 6.16 & \multirow{2}{*}{88.0} & 869 \\
\hline & 2017 & 6.09 & 6.41 & & \\
\hline
\end{tabular}




\begin{tabular}{|c|c|c|c|c|c|}
\hline & 2018 & 6.27 & 6.53 & & \\
\hline & 2019 & 6.08 & 6.14 & & \\
\hline \multirow{4}{*}{ Patriot } & 2016 & 6.75 & 6.88 & \multirow{4}{*}{87.0} & \multirow{4}{*}{87.6} \\
\hline & 2017 & 6.90 & 7.00 & & \\
\hline & 2018 & 6.96 & 7.15 & & \\
\hline & 2019 & 6.91 & 7.13 & & \\
\hline \multirow{3}{*}{ Rapan 2} & 2017 & 7.24 & 7.57 & \multirow{4}{*}{91.0} & \multirow{4}{*}{91.1} \\
\hline & 2018 & 7.37 & 7.89 & & \\
\hline & 2019 & 7.72 & 7.87 & & \\
\hline \multirow{3}{*}{ Kazachok 4} & 2016 & 7.40 & 7.91 & & \\
\hline & 2017 & 7.45 & 8.06 & \multirow{2}{*}{89.7} & \multirow{2}{*}{90.4} \\
\hline & 2018 & 7.91 & 8.07 & & \\
\hline \multirow{2}{*}{ Nautilus } & 2016 & 6.33 & 6.69 & \multirow{2}{*}{86.7} & \multirow{2}{*}{86.8} \\
\hline & 2017 & 6.38 & 6.76 & & \\
\hline \multirow{2}{*}{ Yakhont } & 2016 & 6.61 & 6.95 & \multirow{2}{*}{90.3} & \multirow{2}{*}{90.3} \\
\hline & 2017 & 6.74 & 7.15 & & \\
\hline \multirow{3}{*}{ Azovsky } & 2017 & 6.42 & 6.78 & \multirow{3}{*}{85.1} & \multirow{3}{*}{85.2} \\
\hline & 2018 & 6.70 & 7.05 & & \\
\hline & 2019 & 6.57 & 6.84 & & \\
\hline $\mathrm{LSD}_{05}$ & & 0.05 & 0.06 & 0.52 & 0.58 \\
\hline
\end{tabular}

Rice cultivation at $\mathrm{N}_{120}$ led to an increase in the protein content in polished rice in all varieties in the study. Moreover, the nature of the change in protein content was similar for husked rice. In polished rice, the protein content in relation to husked rice was lower, and the degree of decrease is a criterion for the nutritional value of rice products. In polished rice, PC decreased in two variants of the experiment to $78.9-91.9 \%$ PC in grain, and the indicator did not depend on the variant of the experiment. The indicator indirectly allowed us to estimate the depth of the protein in the caryopsis. A deeper occurrence of protein in the endosperm of the caryopsis was assumed for varieties Rapan, Favorit, Yubileiny 85, Rapan 2, Kazachok 4 and Yakhont (91.0-89.8\%), less deep - in varieties Novator, Flagman, Olimp, Polevik, Yubileiny 85 , Atlant, Kurazh, Patriot, Nautilus and Azovsky (78.9$88.0 \%$ ). Variety Novator was distinguished by the maximum protein loss during polishing, the minimum - Favorit, Rapan and Rapan 2 and Yakhont.

Rice grain is $80-90 \%$ composed of carbohydrates. Amylose is a carbohydrate component of rice starch, a linear polysaccharide in which glucose residues are bound to the first and fourth carbon atoms. Differences in physicochemical properties are a consequence of the ratio of the structural components of starch. The amylose content is considered the most important biochemical indicators of milled rice quality. The results on amylose content in rice grown at different levels of mineral nutrition are presented in Table 2.

Table 2. The amylose content in the grain of rice varieties of Russian breeding, grown under various conditions of nitrogen nutrition.

\begin{tabular}{|l|c|c|c|}
\hline \multirow{3}{*}{ Variety } & \multirow{2}{*}{ Year } & \multicolumn{2}{c|}{ Amylose content in grain of rice varieties. \% } \\
\cline { 3 - 4 } & & variant 1 & variant 2 \\
\hline \multirow{3}{*}{ Rapan } & 2016 & 17.0 & 16.8 \\
\cline { 2 - 4 } & 2017 & 16.8 & 16.5 \\
\cline { 2 - 4 } & 2018 & 16.0 & 15.8 \\
\cline { 2 - 4 } & 2019 & 16.5 & 16.0 \\
\hline \multirow{2}{*}{ Novator } & 2016 & 18.9 & 18.5 \\
\cline { 2 - 4 } & 2017 & 18.5 & 18.3 \\
\hline
\end{tabular}




\begin{tabular}{|c|c|c|c|}
\hline & 2018 & 17.8 & 17.2 \\
\hline & 2019 & 18.3 & 18.0 \\
\hline \multirow{4}{*}{ Flagman } & 2016 & 17.6 & 17.1 \\
\hline & 2017 & 17.2 & 17.0 \\
\hline & 2018 & 16.8 & 16.3 \\
\hline & 2019 & 17.0 & 16.8 \\
\hline \multirow{4}{*}{ Favorit } & 2016 & 19.0 & 18.5 \\
\hline & 2017 & 18.8 & 18.2 \\
\hline & 2018 & 18.0 & 17.5 \\
\hline & 2019 & 18.5 & 18.2 \\
\hline \multirow{4}{*}{ Olimp } & 2016 & 17.9 & 17.3 \\
\hline & 2017 & 17.5 & 17.1 \\
\hline & 2018 & 16.9 & 16.4 \\
\hline & 2019 & 17.3 & 17.0 \\
\hline \multirow{2}{*}{ Polevik } & 2016 & 17.2 & 16.9 \\
\hline & 2017 & 16.7 & 16.3 \\
\hline \multirow{2}{*}{ Yubileyniy 85} & 2016 & 18.1 & 17.4 \\
\hline & 2017 & 17.8 & 17.2 \\
\hline \multirow{4}{*}{ Atlant } & 2016 & 18.4 & 18.0 \\
\hline & 2017 & 18.0 & 17.8 \\
\hline & 2018 & 17.4 & 17.0 \\
\hline & 2019 & 17.9 & 17.5 \\
\hline \multirow{4}{*}{ Kurazh } & 2016 & 16.9 & 16.5 \\
\hline & 2017 & 16.5 & 16.2 \\
\hline & 2018 & 15.5 & 15.0 \\
\hline & 2019 & 15.9 & 15.4 \\
\hline \multirow{4}{*}{ Patriot } & 2016 & 16.9 & 16.7 \\
\hline & 2017 & 16.1 & 15.8 \\
\hline & 2018 & 15.5 & 15.0 \\
\hline & 2019 & 15.8 & 15.4 \\
\hline \multirow{4}{*}{ Rapan 2} & 2016 & 18.2 & 17.9 \\
\hline & 2017 & 17.4 & 17.1 \\
\hline & 2018 & 16.8 & 16.4 \\
\hline & 2019 & 17.0 & 16.7 \\
\hline \multirow{3}{*}{ Kazachok 4} & 2016 & 17.5 & 17.2 \\
\hline & 2017 & 17.1 & 16.8 \\
\hline & 2018 & 16.4 & 16.1 \\
\hline \multirow{2}{*}{ Nautilus } & 2016 & 17.4 & 17.1 \\
\hline & 2017 & 17.3 & 16.9 \\
\hline \multirow{2}{*}{ Yakhont } & 2016 & 19.7 & 19.5 \\
\hline & 2017 & 19.2 & 18.8 \\
\hline \multirow{3}{*}{ Azovsky } & 2017 & 16.3 & 16.0 \\
\hline & 2018 & 15.6 & 15.1 \\
\hline & 2019 & 16.0 & 15.6 \\
\hline $\mathrm{LSD}_{05}$ & & 0.17 & 0.15 \\
\hline
\end{tabular}

The amylose content in variant 2 of the experiment (at $\mathrm{N}_{120}$ ) was reduced in grain of varieties by $0.2-0.7 \%$. By $0.5-0.7 \%$, AC decreased in variety Rapan in 2019 , Novator in 2018, Flagman in 2016 and 2018, Favorit in 2016, 2017 and 2018, Olimp in 2016 and 2018, Yubileyniy 85 - in 2016 and 2017, Kurazh - in 2018 and 2019, Patriot - in 2018, Azovsky - in 2018 For varieties Rapan 2, Polevik, Atlant, Kazachok 4, Nautilus and Yakhont indicator was not higher than $0.4 \%$. A general trend was noted for a more 
significant decrease in AC in varieties in 2018, which is probably due to weather conditions during the rice growing season. All varieties were assigned to the group of low amylose varieties with AC from 15.1 to $19.0 \%$.

\section{Conclusions}

Thus, according to the results of a study of the effect of various doses of nitrogen fertilizers $\left(\mathrm{N}_{90}\right.$ and $\mathrm{N}_{120}$ ) on rice varieties of Russian breeding, 1996-2019, grown in the Abinsky district, Krasnodar region, their reaction to the level of mineral nutrition in relation to biochemical grain quality traits: protein and amylose content was described. With an increase in the level of nitrogen nutrition, an increase in PC in all varieties by $0.03-0.56 \%$ and a decrease in AC by $0.2-0.7 \%$ were noted. Varieties Rapan, Rapan 2, Kozachok 4 were assigned to the group of high-protein. In terms of amylose content, all varieties were low amylose. The nature of decrease in protein content during polishing did not depend on the variant of the experiment.

\section{References}

1. Z.A. Syahariza, S. Sar, J. Hasjim, M.J. Tizzotti, R.G. Gilbert, Food Chem. 136, $742-$ 749 (2013)

2. H. Yoshida, K. Takehisa, T. Kojima, H. Ohno, K. Sasaki, H. Nakagawa, Plant Production Science 19(1), 30-42 (2016)

3. C. Zhou, Y. Huang, B. Jia, Y. Wang, Q. Xu, R. Li, S. Wang, F. Dou, Agronomy 8(11), 246 (2018) doi:10.3390/agronomy8110246.

4. A. Baêta dos Santos, N. Kumar Fageria, L. Fernando Stone, T. Pereira Baêta Santos, Rev. Ceres. 63(5) (2016) doi.org/10.1590/0034-737x201663050018

5. H. Yoshida, K. Takehisa, T. Kojima, H. Ohno, K. Sasaki, H. Nakagawa, Plant Production Science 19(1), 30-42 (2016) DOI 10.1080/1343943X.2015.1128111

6. S. Hotta, K. Takehisa, T. Kitagawa, S. Toritsuka, S. Shimoda, Bulletin of the Shiga Prefecture Agricultural Technology Promotion Center 51, 1 -7 (2013)

7. S. Hotta, K. Takehisa, T. Kitagawa, T. Kojima, T. Nakahashi, S. Toritsuka, S.

Shimoda, The amount of top-dressing nitrogen at panicle formation stage. Annual Meeting of Japanese Society of Soil Science and Plant Nutrition (Kansai Branch, Osaka, Japan, 2011)

8. K. Tanaka, M. Miyazaki, O. Uchikawa, M. Araki, Japanese Journal of Crop Science 79, 450-459 (2010)

9. N. Kheyri, Y. Niknejad, M. Abbasalipour, Ikufīziyuluzhī-i Giyāhān-i Zirầī 12.3(47), 445-460 (2018)

10. S. Peng, R.J. Buresh, J. Huang, and others, Agronomy for Sustainable Development 30, 649-656 (2010)

11. V. Kamaraddi, J. Prakash, Cogent Food \& Agriculture 1(1) (2015) doi $10.1080 / 23311932.2015 .1112675$

12. J. Gu, J. Chen, L. Chen, Z. Wang, H. Zhang, J. Yang, Crop Journal 3(4), 285-297 (2015) doi 10.1016/j.cj.2015.03.007

13. M. Tayefe, A. Gerayzade, S.M. Sadeghl, E. Amiri, Environment and Conservation 16(3), 431-436 (2010) 
14. S. Tao, T. Laga, Z. Shuyu, W. Haiwei, H. Yunfei, Z. Zhongchen, J. Zhengxun, Chinese Journal of Rice Science (CJRS) 32(5), 475-484 (2018) doi: 10.16819/j.10017216.2018 .8013

15. T. Tsukaguchi, Y. Taniguchi, R. Ito, Plant Production Science 19(4), 508-517 (2016) doi 10.1080/1343943X.2016.1223527

16. Y.-J. Song, I.-Y. Choi, P. Kumar Sharma, C.-H. Kang, Plant Production Science 15(4), 253-257 (2012) doi 10.1626/pps.15.253 